DOI https://doi.org/10.18551/rjoas.2018-09.11

\title{
EFFECTS OF TRANSACTIONAL LEADERSHIP ON JOB SATISFACTION, ORGANIZATIONAL COMMITMENT AND INTENTION TO STAY: A STUDY ON EMPLOYEES OF OUTSOURCING COMPANIES IN BANJARMASIN CITY, INDONESIA
}

\author{
Irwansyah*, Astuti Endang Siti, Suhadak, Arifin Zainul \\ Doctoral Degree Program in Administrative Science, Faculty of Administrative Science, \\ University of Brawijaya, Indonesia \\ *E-mail: irwansyah borneo@yahoo.co.id
}

\begin{abstract}
This research aimed to determine the variables influencing the intention to stay of outsourcing employees in Banjarmasin City, South Kalimantan Province. The samples were 218 of a total population of 482 employees from 8 (eight) outsourcing companies. The research data were analyzed using descriptive and inferential statistics, namely Generalized Structured Component Analysis (GSCA). The results showed that all the variables (Transactional Leadership, Job Satisfaction, and Organizational Commitment) significantly affected the intention to stay. The fact underlying this research implementation was that outsourcing companies can absorb a large number of local workers so as to reduce the level of open unemployment in Banjarmasin City. The novelty of this research was the analysis of the effects of transactional leadership and compensation on the intention to stay.
\end{abstract}

\section{KEY WORDS}

Transactional leadership, job satisfaction, organizational commitment, intention to stay.

The hegemony world condition due to the power of global capitalism is increasingly threatening all elements of life. According to Tabb, institutional construction to regulate the world order is carried out through international organizations or agents including WTO (World Trade Organization), GATT (General Agreement on Tariffs and Trade), WB (World Bank), IMF (International Monetary Fund) and other institutions. The capitalism economy emphasizes the role of capital that is all types of wealth, including goods used in other goods production. Capitalism as a comprehensive social system is more than just an economic system. Capitalism has caused adverse effects economically and socially, leading to gaps in people lives. These all are the impact of the cruel capitalism occurring in several developing countries including Indonesia.

The slow economic recovery has caused increased joblessness due to scarce employment, leading to the increased number of poor people. In Indonesia, Law No. 13 of 2013 on Manpower regulates the protection of workers, including outsourcing workers. According to Yuwono (2010), in the outsourcing working pattern, generally, several jobs are handed over to other companies that have legal entities in which one company does not directly deal with workers but only to the worker distributor company. One of the outsourcing working system developments is the improvement of the competitiveness of companies being hit by the economic crisis by reducing expenditure on the employment side. Banjarmasin is the capital city of South Kalimantan Province is a city of government, port, industry, trade and tourism. According to Central Bureau of Statistics, in 2015, Banjarmasin City had a population of 675,440 people with a density of 9,381 people per $\mathrm{km}^{2}$. Banjarmasin is greatly responsible for labor absorption.

To retain employees in an organization is the key for the organization to ensure the implementation of organizational goals. Outsourcing companies employ their employees as the driving source of their activities. Besides, outsourcing companies as the resource transferring companies have an interest in making employees stay in the organization. The intention to stay is highly important to note so that the company's operations certainly continue to run. The high employee turnover can be caused by employee dissatisfaction in the workplace, resulting in weak employee commitment to the organization. Based on the previous studies, the intention to stay can be influenced by job satisfaction. That is, the 
higher employee job satisfaction will lead to the greater intention to stay in the organization (Kudo, 2006). Besides job satisfaction, organizational commitment possessed by a person can influence the intention to stay. Shanker (2013) stated that the higher an employee's commitment is, the bigger his intention to stay in the organization will be. Meanwhile, job satisfaction and organizational commitment can be affected by various factors including leadership. Riaz and Haider (2010) proved the positive effect of transactional leadership on job satisfaction while Othman (2013) found that a positive effect of transactional leadership on organizational commitment.

This research was oriented toward HR management by concerning the effect of leadership, job satisfaction and organizational commitment to the intention to stay in outsourcing companies. The existence of a leader determines the employees' intention to leave or stay in the organization. There are different results between one and another researcher regarding the effect of Transactional Leadership on Job Satisfaction. Riaz and Haider (2010) and Othman (2013) found a positive effect of transactional leadership on job satisfaction and organizational commitment. This is in line with the concept of Burns (1978) describing transactional leadership as follower motivation, primarily through contingent reward-based changes. Bass (1985) revealed that typically, the main focus of transactional leadership is on the goal setting, clarification of the relationship between performance and rewards, and constructive feedback to subordinates in carrying out duties. Differently, Emery and Barker (2007) found an insignificant effect of transactional leadership on job satisfaction and organizational commitment.

The novelty of this dissertation research was the analysis of the effect of transactional leadership on the intention to stay. The intention to stay in organizations is highly influenced by the organizational commitment and individual job satisfaction. Based on the phenomena and previous studies, this research was done to understand the complete relationship model between transactional leadership, job satisfaction, organizational commitment and the intention to stay.

This research was conducted considering the fact that outsourcing companies can absorb a large number of local workers so as to reduce the level of open unemployment in Banjarmasin City. The novelty of this research was the analysis of the effects of transactional leadership on the intention to stay.

Hypothesis. Here are the hypotheses proposed in this research:

$\mathrm{H} 1$ : Transactional Leadership has an effect on Job Satisfaction;

H2: Transactional Leadership has an effect on the Intention to Stay;

H3: Transactional Leadership has an effect on Organizational Commitment;

H4: Job Satisfaction has an effect on Organizational Commitment;

H5: Job Satisfaction has an effect on the Intention to Stay;

H6: Organizational Commitment has an effect on the Intention to Stay.

\section{METHODS OF RESEARCH}

This research was an explanatory research with a quantitative approach. This research discusses the causal relationship and effects between the variables through hypothesis testing.

The sampling was done using a Proportionate Stratified Random Sampling technique. In this technique, the number of samples taken for each stratus is proportional (Sugiyono, 2008) using Slovin formula as follows (in Ridwan, 2005):

$$
\mathrm{n}=\mathrm{N} /\left(1+\mathrm{Ne}^{2}\right)
$$

Where: $\mathrm{n}=$ Number of Samples; $\mathrm{N}=$ Population; $\mathrm{e}=$ Standard of Error.

The level of Standard of Error was set at 0.05 or $5 \%$, meaning that the significance level was at $95 \%$. With the total population of 482 employees, the sample size is measured as 218 employees.

The total sample of 218 employees was obtained through proportional selection with the following distribution (Table 1). 
Table 1 - Number of Samples and the Distribution in Each Work Unit

\begin{tabular}{|c|l|c|c|}
\hline No & Outsourcing Company Name & Population & Sample \\
\hline 1. & PT. PRIMA KARYA SARANA SEJAHTERA & 203 & $203 / 482 \times 218=92$ \\
\hline 2. & PT. PESONA PRIMA UTAMA & 87 & $87 / 482 \times 218=39$ \\
\hline 3. & PT. INTRIAS MANDIRI SEJATI & 33 & $33 / 482 \times 218=15$ \\
\hline 4. & PT.SHANDY PUTRA MAKMUR & 26 & $26 / 482 \times 218=12$ \\
\hline 5. & PT. JATIM SOLUSION & 28 & $28 / 482 \times 218=13$ \\
\hline 6. & PT.ALFABIYA MITRA UTAMA & 39 & $39 / 482 \times 218=18$ \\
\hline 7. & PT.RISSA & 38 & $38 / 482 \times 218=17$ \\
\hline 8. & PT.PRISMA JAMINTARA & 28 & $28 / 482 \times 218=12$ \\
\hline \multicolumn{2}{r}{ Total } & 482 & 218 \\
\hline
\end{tabular}

Source: Processed Data (2018).

The data analysis method used in this research was a descriptive and inferential statistics, namely Generalized Structured Component Analysis (GSCA).

The validity test results of this research can be seen in the following table:

Table 2 - Validity Test Results

\begin{tabular}{|c|c|c|c|c|c|}
\hline Variable & Dimension Indicator & Item & $\begin{array}{c}\text { Validity } \\
\text { Coefficient }\end{array}$ & $\begin{array}{l}\text { Cut } \\
\text { Off }\end{array}$ & Des. \\
\hline \multirow{6}{*}{ Transactional Leadership } & \multirow{2}{*}{ Contingent reward } & $\mathrm{X} 1.1 .1$ & 0.938 & 0.3 & Valid \\
\hline & & $\mathrm{X} 1.1 .2$ & 0.938 & 0.3 & Valid \\
\hline & \multirow{2}{*}{ Management by exception (Active) } & $\mathrm{X} 1.2 .1$ & 0.895 & 0.3 & Valid \\
\hline & & $\mathrm{X} 1.2 .2$ & 0.940 & 0.3 & Valid \\
\hline & \multirow{2}{*}{ Management by exception (Passive) } & $\mathrm{X} 1.3 .1$ & 0.889 & 0.3 & Valid \\
\hline & & $\mathrm{X} 1.3 .2$ & 0.897 & 0.3 & Valid \\
\hline \multirow{11}{*}{ Job Satisfaction } & \multirow{2}{*}{ Satisfaction with salary } & $\bar{Y} 1.1 .1$ & 0.850 & 0.3 & Valid \\
\hline & & $\mathrm{Y} 1.1 .2$ & 0.930 & 0.3 & Valid \\
\hline & \multirow{2}{*}{ Satisfaction with supervision } & Y1.2.1 & 0.923 & 0.3 & Valid \\
\hline & & Y1.2.2 & 0.901 & 0.3 & Valid \\
\hline & \multirow{3}{*}{ Satisfaction with promotion } & $\mathrm{Y} 1.3 .1$ & 0.708 & 0.3 & Valid \\
\hline & & Y1.3.2 & 0.809 & 0.3 & Valid \\
\hline & & Y1.3.3 & 0.737 & 0.3 & Valid \\
\hline & \multirow{2}{*}{ Satisfaction with the job itself } & Y1.4.1 & 0.868 & 0.3 & Valid \\
\hline & & Y1.4.2 & 0.866 & 0.3 & Valid \\
\hline & \multirow{2}{*}{ Satisfaction with colleagues } & Y1.5.1 & 0.908 & 0.3 & Valid \\
\hline & & $\mathrm{Y} 1.5 .2$ & 0.796 & 0.3 & Valid \\
\hline \multirow{6}{*}{ Organizational Commitment } & \multirow{2}{*}{ Affective commitment } & Y2.1.1 & 0.865 & 0.3 & Valid \\
\hline & & Y2.1.2 & 0.859 & 0.3 & Valid \\
\hline & \multirow{2}{*}{ Continuous commitment } & Y2.2.1 & 0.910 & 0.3 & Valid \\
\hline & & Y2.2.2 & 0.898 & 0.3 & Valid \\
\hline & \multirow{2}{*}{ Normative commitment } & Y2.3.1 & 0.876 & 0.3 & Valid \\
\hline & & $\mathrm{Y} 2.3 .2$ & 0.930 & 0.3 & Valid \\
\hline \multirow{4}{*}{ Intention to Stay } & \multirow{2}{*}{ Thinking to stay } & Y3.1.1 & 0.862 & 0.3 & Valid \\
\hline & & Y3.1.2 & 0.877 & 0.3 & Valid \\
\hline & \multirow{2}{*}{ Thinking another job } & Y3.2.1 & 0.900 & 0.3 & Valid \\
\hline & & Y3.2.2 & 0.851 & 0.3 & Valid \\
\hline
\end{tabular}

Source: Processed Data (2018).

The summary of the reliability test results can be seen in Table 3 below:

Table 3 - Summary of Reliability Test Results

\begin{tabular}{|c|c|c|c|c|}
\hline Variable & Indicator & Reliability Coefficient & Cut Off & Des. \\
\hline \multirow{3}{*}{ Transactional Leadership } & Contingent reward & 0.864 & 0.6 & Reliable \\
\hline & Management by exception (Active) & 0.799 & 0.6 & Reliable \\
\hline & Management by exception (Passive) & 0.746 & 0.6 & Reliable \\
\hline \multirow{5}{*}{ Job Satisfaction } & Satisfaction with salary & 0.718 & 0.6 & Reliable \\
\hline & Satisfaction with supervision & 0.795 & 0.6 & Reliable \\
\hline & Satisfaction with promotion & 0.612 & 0.6 & Reliable \\
\hline & Satisfaction with the job itself & 0.670 & 0.6 & Reliable \\
\hline & Satisfaction with colleagues & 0.610 & 0.6 & Reliable \\
\hline \multirow{3}{*}{ Organizational Commitment } & Affective commitment & 0.655 & 0.6 & Reliable \\
\hline & Continuous commitment & 0.776 & 0.6 & Reliable \\
\hline & Normative commitment & 0.760 & 0.6 & Reliable \\
\hline \multirow{2}{*}{ Intention to Stay } & Thinking to Stay & 0.677 & 0.6 & Reliable \\
\hline & Thinking Another Job & 0.691 & 0.6 & Reliable \\
\hline
\end{tabular}

Source: Processed Data (2018). 


\section{RESULTS OF STUDY}

Linearity and Goodness of Fit Tests. The hypothesis testing on GSCA was done using a resampling approach with a Bootstrap method, so it did not require data normality assumption. Assumption required in GSCA is the effect between linear variables. This assumption testing results can be seen in Table 4:

Table 4 - Results of Linearity Assumption Testing

\begin{tabular}{|c|c|c|c|c|c|}
\hline \multicolumn{3}{|c|}{ Relationship between Variables } & $\mathrm{F}$ & Sig. & Des. \\
\hline 1. & Transactional Leadership & Job satisfaction & 14.126 & 0.000 & Linear \\
\hline 2. & Transactional Leadership & Organizational commitment & 16.939 & 0.000 & Linear \\
\hline 3. & Job Satisfaction & Organizational commitment & 102.671 & 0.000 & Linear \\
\hline 4. & Job Satisfaction & Intention to stay & 55.112 & 0.000 & Linear \\
\hline 5. & Organizational Commitment & Intention to stay & 97.244 & 0.000 & Linear \\
\hline 6. & Transactional Leadership & Intention to stay & 32.695 & 0.000 & Linear \\
\hline
\end{tabular}

Source: Processed Data (2018).

Based on Table 4 above, it can be seen that all the relationships between variables were linear, thus the linearity assumption was fulfilled. The measures of Goodness of Fit model in GSCA were in the forms of FIT and AFIT. The results of the Goodness of Fit test in this research model are presented as follows:

Table 5 - Goodness of Fit Model

\begin{tabular}{|c|c|}
\hline FIT Model & Value \\
\hline FIT & 0.494 \\
\hline AFIT & 0.488 \\
\hline
\end{tabular}

Based on Table 5 above, the goodness of fit-inner model showed a FIT value of 0.494 , indicating that the research model could explain the effect of several variables (according to the model in the conceptual framework) on the variable of Intention to Stay with a significance level of $49.4 \%$. That is, the contribution of the effects of other variables outside this research model added with the error was $48.8 \%$.

Table 6 - Results of Hypothesis Testing

\begin{tabular}{|c|c|c|c|c|c|c|}
\hline Hypothesis & Exogenous & Endogenous & Path Coefficients & SE & CR & Des. \\
\hline H1 & TL & JS & 0.210 & 0.095 & 2.21 & Significant \\
\hline H2 & TL & ITS & 0.232 & 0.082 & $2.83^{*}$ & Significant $^{*}$ \\
\hline H3 & TL & OC & 0.125 & 0.075 & 1.67 & Not Significant \\
\hline H4 & JS & OC & 0.583 & 0.088 & $6.63^{*}$ & Significant \\
\hline H5 & JS & ITS & 0.272 & 0.083 & $3.28^{*}$ & Significant $^{*}$ \\
\hline H9 & OC & ITS & 0.431 & 0.078 & $5.53^{*}$ & Significant \\
\hline
\end{tabular}

Note: *= significant at a 5\%. Source: Processed Data (2018).

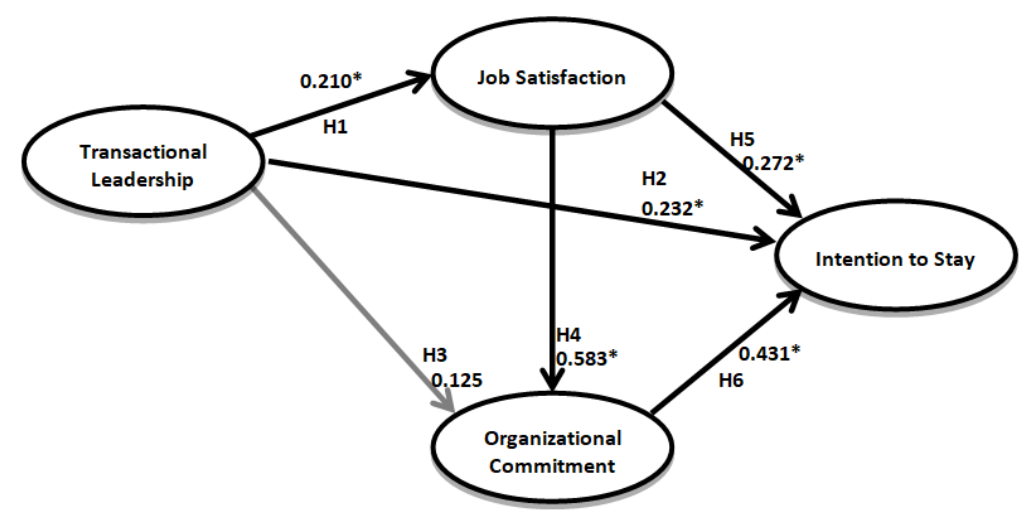

$\longrightarrow$ Significant $\quad \longrightarrow$ Not Significant

Figure 1 - Path Diagram of Hypothesis Testing 
In this research, there were 3 (three) endogenous variables and 1 (one) exogenous in which the effect of one on another was measured. Effects of the Transactional Leadership variable were measured on the Job Satisfaction, Organizational Commitment, and Intention to Stay variables. Moreover, the effects of the Job Satisfaction variable were measured on the Organizational Commitment and Intention to Stay variables. The Organizational Commitment variable was measured for its effect on the Intention to Stay. Further explanation of the effects between variables in this research is as follows.

The Effect of Transactional Leadership on Job Satisfaction (H1). The results of this research proved that Transactional Leadership $\left(\mathrm{X}_{1}\right)$ significantly affected Job Satisfaction $\left(Y_{1}\right)$ with a path coefficient of 0.210 and $C R$ of $2.21^{*}$. These values indicate that the better implementation of transactional leadership through the indicators of Contingent reward, Management by exception (Active), and Management by exception (Passive) increased the job satisfaction level of employees working at outsourcing companies in South Kalimantan. Leaders are role models for subordinates and greatly determine the performance of subordinates. Leadership can be interpreted as the ability to influence groups to be able to achieve organizational goals (Robbins, 2003: 324), and in a dynamic environment, we need leaders to face the status quo conditions to create a future vision and inspire organizational members to realize the vision. According to Bass and Avolio (1994), transactional leaders try to motivate their subordinates by giving rewards for what they do.

Job satisfaction is usually related to the theory of justice, and motivation. Job satisfaction is influenced by the reward size and individual engagement in the job. The reward size may not be a big problem as long as it is considered fair by the employees who receive it. Realizing this, one of the important targets in human resource management is the creation of job satisfaction for organizational members so as to increase their performance. With high job satisfaction, employees are expected to maximize their working and be willing to do works beyond their responsibilities so as to accelerate the process of achieving organizational goals.

These results support Riaz and Haider (2010) finding that transactional leadership positively affects job satisfaction, but are not consistent with Ermery and Barker (2007) stating that transactional leadership does not correlate with job satisfaction. Meanwhile, Burns (1978) argued that transactional leaders try to motivate subordinates through rewards for what they do. Transactional leaders believe the ability of subordinates, making subordinates confident to work independently. Subordinates are expected to maintain their work quality according to the standards, and the leaders will take actions only if there are problems leading to job failure (the actions can vary and provide information about what happened and how to make improvements up to the subordinate dismissal from their jobs).

The Effect of Transactional Leadership on the Intention to Stay (H2). The results of this research showed that Transactional Leadership $\left(X_{1}\right)$ significantly affected the Intention to Stay $\left(\mathrm{Y}_{3}\right)$ with a path coefficient of 0.232 and $\mathrm{CR}$ of $2.83^{*}$. Based on these values, it can be explained that the level of Transactional Leadership would affect the Intention to Stay.

According to Tett and Meyer (1993), the intention to stay is a conscious willingness to stay in an organization. There are various reasons underlying employee willingness to work for a company. The most common reason is that employees are social creatures who need others (groups or organizations). Employees have limitations in meeting their various needs which can only be achieved or fulfilled with the assistance of or jointly with others through organizations. The needs of employees certainly vary (Maslow, 1975; Mc Clelland in Manundar, 2010; and Alderfer in Mangkunegara, 2010) and have different intensity levels and are very dynamic, developing along with the demands of changes in the surrounding environment. In addition to motivating subordinates through rewards for what they do, a transactional leader often follows employees' desires to just make them stay in the organization. The employees' needs are expected to be fulfilled by companies through the better management practices of human resources.

The Effect of Transactional Leadership on Organizational Commitment (H3). The results of this research showed that Transactional Leadership $\left(\mathrm{X}_{1}\right)$ did not significantly affect Organizational Commitment $\left(\mathrm{Y}_{2}\right)$ with a path coefficient of 0.125 and CR of 1.67. These 
values were considered as critical values, so the strength of the effect between both variables was included into the low category. In other words, the implementation of transactional leadership had no effect on the level of organizational commitment.

According to Steers and Porter (1983), a form of commitment emerging is not only passive loyalty but also involves an active relationship with work organizations that have the aim of providing all efforts for the success of the organization concerned. Furthermore, Steers and Porter stated that low commitment reflects a form of employee attachment to the organization. In carrying out activities to help the organization achieve its goals, employees highly depend on the rewards or feedback given by the organizations. In other words, employees' organizational commitment is not generated by the pure encouragement from within the individual or the conformity of values possessed by the individual. These results support Emery and Barker (2007) suggesting that transactional leadership does not correlate with organizational commitment. In contrast, Othman (2013) found that transactional leadership influences organizational commitment, strengthen by Setyaningdyah et al. (2013) and Dhammika (2013) who also found a significant effect of transactional leadership on organizational commitment.

The Effect of Job Satisfaction on Organizational Commitment (H4). The results of this results suggested that Job Satisfaction $\left(Y_{1}\right)$ significantly affected Organizational Commitment $\left(Y_{2}\right)$ with a path coefficient of 0.583 and $C R$ of $6.63^{*}$. It means that the level of Job Satisfaction given by the companies would affect the Organizational Commitment of outsourcing employees.

From the point of view of the community and individual employees, job satisfaction is the desired outcome. Employees with high job satisfaction tend to have better physical health, learn tasks related to new jobs more quickly, have fewer workplace accidents, less complain, and have a low-stress level (Luthans, 2006). Besides, employees with high job satisfaction feel contented in doing their jobs and not try to seek other alternative jobs. Conversely, employees who are dissatisfied with their jobs tend to seek other alternative jobs and choose to quit the company because they expect a more satisfying job (Modley, 1979).

These results support Abeer Imam et al. (2013) finding that job satisfaction significantly influences organizational commitment (affective, continuous and normative commitment). It is further strengthened by Khan and Jan (2014) stating that job satisfaction, especially related to salary, promotion, and work environment, positively affects organizational commitment.

The Effect of Job Satisfaction on the Intention to Stay (H5). The results of this research exhibited that Job Satisfaction $\left(Y_{1}\right)$ had a significant effect on the Intention to Stay $\left(Y_{3}\right)$ with a path coefficient of 0.272 and $\mathrm{CR}$ of $3.28^{*}$. These values indicate that the higher Job Satisfaction would increase the Intention to Stay.

In other words, someone decides to apply for a job in a certain company because he wants to fulfil his needs and he expects that the needs can be fulfilled by the company where he works. These needs are the most basic motive or reason underlying the employee willingness to work for the company. The needs of employees certainly vary (Maslow, 1975; Mc Clelland in Manundar, 2010; and Alderfer in Mangkunegara, 2010) and have different intensity levels and are very dynamic, developing along with the demands of changes in the surrounding environment. Besides, these needs are what employees expect to be fulfilled by companies through good resource management practices. The results of this research support Kudo (2006) explaining that job satisfaction strongly affects the intention to stay, especially of senior workers.

The Effect of Organizational Commitment on the Intention to Stay (H6). As proved by this research, Organizational Commitment $\left(\mathrm{Y}_{2}\right)$ significantly affected the Intention to Stay $\left(\mathrm{Y}_{3}\right)$ with a path coefficient of 0.431 and CR $5.53^{*}$. These values indicate that the implementation of organizational commitment would impact the level of the intention to stay.

Employees' organizational commitment is an important behavioral dimension that can be used to measure and evaluate the extent to which employees can survive and carry out their duties and obligations in the company. Knowing employees' organizational commitment possessed, a company can direct its policies with a strong and empowered capital of human 
resources. Commitment is a condition felt by employees, leading to strong positive behavior towards the organization. The results of this research are consistent with Shanker (2013) discovering that organizational commitment influences the intention to stay.

Research Implication. This research contributes theoretically and practically regarding the effect of transactional leadership on job satisfaction, organizational commitment and the intention to stay of outsourcing employees in Banjarmasin City). The implications of this research are expected to benefit the development of science, especially on outsourcing companies in Banjarmasin City.

Theoretical Implication. The findings of this research are expected to contribute theoretically in terms of scientific development that is as a test material and clarification of the theories developed in this research and its consistency with the previous studies.

The theoretical implications of this research are explained further as follows:

- This research becomes an empirical basis in the development of the Transactional Leadership theory developed by Bass \& Avio (1994), and reinforces the previous studies, including Riaz and Haider (2010) and Robert et al. (2014), finding a significant direct effect of Transactional Leadership variable on Job Satisfaction. Thus, empirically, transactional leadership has a significant effect on job satisfaction.

- This research constitutes an empirical basis in the development of the Transactional Leadership theory developed by Bass \& Avio (1994) and supports the results of previous studies showing a significant direct effect of Transactional Leadership variable on the Intention to Stay. Thus, empirically, it can be said that transactional leadership significantly affects the intention to stay.

- This research becomes an empirical basis in the development of the Transactional Leadership theory developed by Bass \& Avio (1990), and supports the results of previous studies, including Ermery and Barker (2007), stating that Transactional Leadership variable has no significant direct effect on Organizational Commitment. Thus, empirically, it is concluded that transactional leadership has no significant effect on organizational commitment.

- This research empirically underlies the development of the job satisfaction theory developed by Luthans (2006) and strengthens the previous studies, including Abeer Imam et al. (2013) and Khan and Jan (2015), finding a significant direct effect of Job Satisfaction variable on Organizational Commitment. Thus, empirically, job satisfaction has a significant effect on organizational commitment.

- This research constitutes an empirical basis in the development of the Job Satisfaction theory developed by Luthans (2006) and supports the testing results of previous studies, including Kudo (2006), showing a significant direct effect of Job Satisfaction variable on the Intention to Stay. Accordingly, it is obtained that, empirically, job satisfaction significantly affects the intention to stay.

- This research also becomes an empirical basis in the development of the Organizational Commitment theory developed by Meyer and Alien (1996) and the Intention to Stay theory developed by Tett and Meyer (1993), as well as supports the results of previous studies, including Shanker (2013), indicating a significant direct effect of Organizational Commitment variable on the Intention to Stay. Thus, empirically, organizational commitment significantly affects the intention to stay.

Practical Implication. In addition to the theoretical implications, the findings of this research provide practical contributions that can be used as an input for outsourcing companies in Banjarmasin City:

- The results of this research proved that Transactional Leadership significantly affected Job Satisfaction and the Intention to Stay, but not significantly affected Organizational Commitment. This implies that transactional leadership can provide outsourcing company employees with job satisfaction so as to generate their intention to stay and encourage their commitment to work;

- Outsourcing company leaders need to increase job satisfaction and organizational commitment so that employees intend to stay with the company. 


\section{CONCLUSION}

Transactional leadership has a significant effect on the employees' job satisfaction in outsourcing companies in Banjarmasin. It can be interpreted that transactional leadership through the indicators of contingent reward, management by exception (active), and management by exception (passive) can significantly affect job satisfaction. That is, if transactional leadership applied by leaders is increasingly acceptable to employees, the employees' job satisfaction will get higher.

Transactional leadership has a significant effect on the employees' intention to stay in outsourcing companies in Banjarmasin. It can be interpreted that transactional leadership through the indicators of contingent reward, management by exception (active), and management by exception (passive) can significantly affect the intention to stay. That is, if transactional leadership applied by leaders is increasingly acceptable to employees, the employees' intention to stay will get stronger.

Transactional leadership has no significant effect on the employees' organizational commitment in outsourcing companies in Banjarmasin. It indicates that transactional leadership through the indicators of contingent reward, management by exception (active), and management by exception (passive) insignificantly affects organizational commitment. That is, if transactional leadership applied by leaders is increasingly acceptable to employees, the organizational commitment will get higher but not too significant.

Job satisfaction has a significant effect on the employees' organizational commitment in outsourcing employees in Banjarmasin. It can be interpreted that job satisfaction through the indicators of salary, satisfaction with supervision, satisfaction with the job itself, and satisfaction with colleagues can significantly affect organizational commitment. That is, the higher the employees' job satisfaction is, the higher their organizational commitment will be.

Job satisfaction has a significant effect on the employees' intention to stay in outsourcing companies in Banjarmasin. It means that job satisfaction through the indicators of salary, satisfaction with supervision, satisfaction with the job itself, and satisfaction with colleagues can significantly affect the intention to stay. In other words, the higher the employees' job satisfaction is, the stronger their intention to stay will be.

Organizational commitment has a significant effect on the employees' intention to stay in outsourcing companies in Banjarmasin. It can be interpreted that organizational commitment through the indicators of affective, continuous, and normative commitment can significantly affect the intention to stay. That is, the higher the employees' organizational commitment is, the stronger their intention to stay will be.

Limitation and Suggestion for Further Studies. Some limitations of this research can be used as a reference for future researchers. First, this research was only focused on one type of outsourcing job, namely cleaning service, thus the results of this research cannot be generalized to other types of outsourcing jobs. Second, in the respondent selection, male and female workers were not differentiated. To enrich the findings, future studies on the effect of transactional leadership on employee performance are suggested to explore the transactional leadership style.

\section{REFERENCES}

1. Bass, B.M. 1985. Leadership and performance Beyond Expectation. Free Press. New York.

2. Bass, B.M. 1990. "From transactional to transformational leadership: earning to share the vision, Organizational Dynamics" Winter: pp. 19-31

3. Bass, B.M. and B.J. Avolio. 1994. Manual for Mulfifactor Leadership Questionnaire. CA. Consulting Pschologist press. Palo Alto.

4. Burns, J.M. 1978. Leadership. Harper \& Row. New York.

5. Dhammika, K.A.S. 2013. Transactional, Transformational, Union and Organizational Commitment: An Examination of the Effect Flaws. International Journal of Business and Social Science', Vol. 4, No. 6: june 
6. Emery, C.R. and Barker, K.J. 2007. The Effect Of Transactional And Transformational Leadership Styles On The Organizational Commitment and Job Satisfaction Of Customer.

7. Kudo, Y. 2006. "Association between Intention to stay on the job and Job Satisfaction among japanase Nurses In Small and Medium Sized Private Hospital, Journal Of Occupational Health"48: 504-513

8. Luthans, F. 2006. Perilaku Organisasi. Yogyakarta: Penerbit Andi.

9. Mangkunegara, A.P. 2010. Perilaku dan Budaya Organisasi. Reflika Aditama. Bandung.

10. Mancini, B.A. 2007. The Relationship of Transformational and Transactional Leadership to Job Satisfaction and Organization Commitment within for-Profit Organization on Long Island. Dissertation. Dowling College, New York.

11. Meyer, J.P. \& Allen, N.J. "1996. A Tree - Component Conseptualitation of Organizational Commitment. Human Resource Management Review" Vol. 11, No.1

12. Mondey, R.W. and Noe, R.M. 1993. Human Resources Management. Allyn \& Bacon. Boston.

13. Munandar, A.S. 2001. Psikologi Industri dan Organisasi. Penerbit Universitas Indonesia. Jakrta.

14. Othman, J. 2013 "Does a Transformational and Transactional Leadership Style Predict Organization Commitment " Asian Social Science;Vol 9,No.1:2013

15. Porter, L. and R, M. Steers. 1983. Organizational, Work, and Personal factors in Employee Turnover and Absteeism. Psychological Bulletin.

16. Riaz, A. and Haider, M.H. 2010. "Role of transformational and transactional leadership on job satisfaction and career satisfaction. Business and Economic Horizons, Vol. 1: pp. 29-38.

17. Robbins, S.P. 2003. Perilaku Organisasi. PT. Indeks Kelompok Gramedia. Jakarta.

18. Khan, A.F. and Jan, F. 2015. "The Study of Organization Commitment and Job Satisfaction among Hospital Nurses. A Survey of District Hospitals of Dera Ismail Khan. Global Journal of Management and Business Research: A Administration and Management, Vol. 15, No. 1.

19. Setyaningdyah, E., Kertahdi, U., \& Thayib, A. 2004. "The Effects of Human Resource Competence, Organisational Commitment and Transactional Leadership on Work Discipline, Job Satisfaction and Employee'sPerformance. Interdisciplinary Journal Of Contemporary Research In Business, Vol. 5, No. 4.

20. Shanker, M. 2013. "Organizational Commitment and Employees' Intention to Stay in Indian Companies: Factor Analytical Approach, Journal of Psychosocial Research" Vol. 8, No. 2: $199-208$

21. Sugiono. 2008. Metode Penelitian Bisnis. Alfabeta. Bandung.

22. Tett, R.P \& Meyer, J.P. 1993. "Job Satisfaction, Organizational Commitment, Turover Intention and Turnover: Path Analysis Based on Meta Analytic Findings. Personnel Psychology, Summer: pp. 259-293

23. Yuwono, D.I. 2010. Pedoman Terbaru Outsourcing \& Kontrak Kerja: Peraturan 2012 Tentang Outsourcing dan Perjanjian Kerja Waktu Tertentu (PKWT). Pustaka Yustisia. Yogyakarta. 